Milena Tsvetkova, Yuri Kolin, Yuliya Bakhnova, Svetlana Salimova

\title{
The importance of separating the author from the narrative in modern and classical literature
}

\section{Introduction}

In the late twentieth and early twenty-first centuries, narratology has developed considerably as a field of study that examines the relationship between the basic types of narrative voice and character.

Narratology involves the comprehensive analysis of a literary work in terms of features, patterns and rules of storytelling. The research attention devoted to narrative discourse, which intensified at the beginning of the twentieth century, is a completely logical thing in the history of philology, since it reflects the attempts to more accurately interpret the work and identify typological patterns of creativity both of a particular artist and of a certain literary school. The author's identity as one of the main categories of a literary text, the importance of which is associated with the anthropocentrism of literature, is of a complex structure in prose; it is a system of elements whose specificity is determined by the individual and artistic style of the writer and general aesthetic tasks. All linguistic units in the lexical content of the author's identity are semantically loaded; in fiction, a conscious selection of linguistic means is carried out. At the level of linguistic embodiment, it makes the analysis of the structure and semantics of images important for the further study of the content and specificity of the laws of writing text. The combination of language tools embodies the semantics of the image of the character, and the study of the author's elements at the language level reveals the author's intentions and style of writing and the author's national image of the world.

An important task of narratology is the study of the author's representation in a literary text, the degree of identity of the real author (biographical) with the narrator. This is especially relevant to autobiographical literature, which implies the proximity of these concepts. All this makes it important to study the author's identity as one of the most semantically loaded components of a prose work in order to analyse the features of the author's creative manner, to identify his or her place in the literary process, as well as to conceptualize the literary process as a whole to determine the general vector of narrative discourse. A comparison of the author's representations in 
autobiographical works by various national authors (Kazakh, Russian and American) is considered to be relevant in a synchronous aspect. The study of the author's representations in national literature is also important not only from the perspective of differentiation, but also integration as it makes it possible to reveal common and universal features of national image of the world in a work of art.

\section{Literature review}

Orlova (2017) indicates that it is important to distinguish between the subject of speech (the speaker) and the subject of consciousness (the one whose consciousness is expressed at the same time). In the narrative, there is a certain "diffusion" of the voices of the author and the characters. Kopytov (2010) proposes distinguishing three speakers in a literary text: a natural speaker (the author), and two mental (ideal) speakers (the narrator (I) and the character (you and he)).

Bogdanova (2016) introduces the concepts of "speech producer" (a real person with their own biography and, consequently, experience, traits and beliefs who produces a speech message and a text) and "subject of speech" (an author, a lyrical character, a narrator, various characters), which is a kind of intermediary between the author, the reader and the character of the work that transmits information. However, this is a product of the author's modelling of the image of the speaking person. According to the researcher, the author's identity is "a personal attitude embodied in the text to the subject of the image".

The nature of the text and its subjective modality are determined by the author's attitude to the described events and reality (Moroz, 2017, 29; Rakhmatova, 2017, 112).

In the second half of the 20th century, according to Chemodurova, autobiographical narratives that problematized the relationship between fact and fiction became especially popular as postmodern philosophy significantly complicated the subjectobject relationship, the narrative subject had multiple layers, and the ambiguous structure of Auto + Bio + Graphics was transformed into Auto + Fiction (Chemodurova, 2019, 53). Chemodurova believes that one of the most important reasons contributing to the transformation of autobiographical discourse and its elements into a significant discourse is the authors' tendency towards playful reflection on the problem of demarcation / juxtaposition of reality and fiction, which was intensified at the end of the 20th century by the desire for self-identification and self-knowledge in a chaotic and unpredictable world, which led to experimentation with traditional narrative modes (Chemodurova, 2019, 53).

The arguments by Yankovskaya (2018) are important for understanding the specifics of autobiographical prose. She states that the subject-object relationship of the author and the main character in an autobiographical or auto-psychological text is 
determined by the degree of proximity of the text to the biographical and documented reality. The distance between these models determines the degree of reliability or fiction of the narrative (Yankovskaya, 2018, 89).

Subjectivity in autobiographical works can be manifested in different ways. According to Wang Jiao, these include the selection of facts, the structure of the plot, the features of creating the image of an autobiographical character, the construction of a fact, handling of fiction, etc. (Jiao, 2019, 51). Jiao insists that "the introduction of fiction in autobiography should not weaken the core of the works of the genre - the actual truthfulness as a whole. Meanwhile, the active and extensive use of fiction in autobiography changes autobiographical writing, thereby creating a certain pastiche, that is quasi-autobiography or pseudo-autobiography" (Jiao, 2019, 51).

The purpose of the study is to analyse the autobiographical works by contemporary Kazakh, Russian and American writers of the late twentieth and early twenty-first centuries belonging to the post-colonial and post-totalitarian discourses in terms of the specificities of the authors' representations of their national images of the world.

The implementation of this goal involves solving the following tasks:

- to actualize the problems and prospects of the study of the autobiographical novel through the prism of the post-colonial and post-totalitarian paradigms;

- to conduct a comparative analysis of the works by Kazakh, Russian and American writers of the late twentieth and early twenty-first centuries in terms of the genre, poetic and narrative aspects;

- to analyse the correlation between the real (biographical) author and the representation of the author in his or her autobiographical works;

- to demonstrate that a certain distance of the author from the character is determined by the desire of the real author to increase the typicality and universality of his or her own life story.

\section{Methods and materials}

The research subject is revealed through the integration of contextual and syntheticanalytical approaches to the study of the author's representation in autobiographical literature. The features of the study, its purpose and objectives led to the use of the following set of methods: systemic (aimed at systematizing theoretical and literary-critical views on the types of author's representations in a literary text, as well as determining the essence and narrative specifics of autobiographical literature); genetic (aimed at studying the nature of the genre being analysed and the determination of further stages of its development); comparative-typological (in order to determine the genre and national characteristics of the analysed autobiographical works, the characteristics 
of their role and place in the modern literary process); descriptive analysis (in order to identify the features of the author's representations in autobiographical works); holistic analysis of a literary text (aimed at studying the poetics of the works being analysed). The biographical method shows how the author's identity and important sociohistorical and cultural problems of the era are reflected in autobiographical works. The multi-genre, sociocultural, narrative, intermedial interpretation approaches make it possible to reveal the originality of the author's representations as well as specific approaches to expressing the national image of the world in various national autobiographical texts.

The object of the study is the autobiographical novels by modern Kazakh, Russian and American authors of the late twentieth and early twenty-first centuries as a manifestation of the same cultural development stage from the perspective of the author's representations, the construction of the author's image, genre and thematic originality, poly-stylistics and multidimensional artistic thinking in the context of the world literary process.

The subject of the study is the specifics of narration, the image of the author, the introduction of fiction and stylization elements in the autobiographical novel.

The research material includes the following autobiographical works $A$ Life at Noon by Talasbek Asemkulov, Jacob's Ladder by Lyudmila Ulitskaya and Roots by Alex Haley, with the first being one that is relatively little known to the world. The inclusion of the writer's artistic heritage in a wider literary context determines the future research prospects.

The choice of the illustrative material is determined by the desire to consider the most representative texts of a certain genre (an autobiographical novel) and a similar problem, which is the recognition of national and cultural identity in the context of oppression (colonial, totalitarian, racial, national) and discrimination.

\section{Results and discussion}

The autobiographical novel by the Kazakh writer Talasbek Asemkulov, A Life at Noon (2003), is based on real historical events and the author's memories of childhood and youth (the 1960s) spent in a mountain village in East Kazakhstan.

Asemkulov's creative career was predetermined in his childhood: his grandfather Sabyt, a famous Kazakh kyui performer, took the boy to his place in infancy so that he would inherit what he knew of folk musical art, and thus he could raise a successor of traditions, a bearer of primordial national values, and an expert in the steppe art and mythology. The atmosphere and daily life of a small mountain village are thoroughly conveyed in the novel. The main theme is the relationship between grandfather and grandson and their creative communication aimed at transmitting 
sacred and core national knowledge. By examining the degree of identification of the narrator, it can be argued that the character of the narrative is personally labelled through the author's real persona. However, the author distances himself from the character he has created through the use of third-person statements. Moreover, the key idea of the narrative is based on the depiction of the historical, cultural and social reality of Kazakhstan, and the narrator himself is an instrument of describing the idea. Real-life cases are represented from the perspective of cultural transmission: the boy's conflicts with his comrades actualize the topic of selectivity and heroism; a trip to the forge draws a symbolic parallel between the fate of an individual person and the whole nation that is voiced by the author through the blacksmith Akhmetzhan: "Iron is rotted, killed several times, black curly rust is melted several times. In the end, the iron returns to its infancy; then, it is bent countless times, kneaded like a dough, and pulled like kamcha." ${ }^{1}$

The grandfather tells his grandson the tragic history of the Kazakhs: revolution, relocation to China, famine, repression (Sabyt spent more than twenty years in Stalin's labour camps), crowding out of national culture and the disappearance of its bearers.

The novel is characterized by the complex relationship between the author as a real person and the image of the author. T. Asemkulov tells a story in the third person narrative mode and gives the main character a different name in order to distance himself. Adjigerey is both the real Talasbek Asemkulov and a fictional character. Azizova and Dzholdasbekova (2016), researchers of Kazakh literature, point out that "in fact, the character lives in two different worlds (the real world and the imaginary world), but the writer insists that he relied on his personal experience and wanted the reader to place faith in the facts about the fate of the Kazakh culture described in the novel". The author's position and ideological content are transmitted not only through the image of the narrator, but also through the system of characters, cultural and historical background that constitutes the author's image of the world. The separation of the narrative from the real persona of the author is obvious, since the writer is the subject of creating a fiction text through linguistic means. The direct narrative operates separately from the author, as it is the main object of revealing the cultural values of the people, which are preserved and transmitted in writing through generations.

The autobiographical novel “Jacob's Ladder" (2015) by L. Ulitskaya contains the same specifics of the author's representation. Unlike T. Asemkulov, she focuses on the intellectual and spiritual dialogue between a granddaughter (Nora) and grandfather (Yakov Osetskiy) - they "met" when Nora read the diary and correspondence

1 In the same place cited 
of her deceased grandfather and then studied his personal file in the archive of the Committee for State Security. The novel is mainly based on the culture destroyed by the totalitarian regime, interrupted links between generations and music as a cultural bridge. In Yakov Osetsky's diary observations of life, descriptions of events and reflections are interspersed with music.

The writer uses the mode of transgression, which suggests that she goes beyond her own life experience to create a separate narrative with its system of characters and morality. The narrative is ostensibly distinct from the moral and cultural makeup of the writer, thereby detaching itself from the writer's persona. In this work it is also possible to observe a subject-object relationship between author and narrative, where the artistic text is the central object that only the authorship is bound to.

The autobiographical novel by the African-American author Alex Haley, "Roots" (1976), tells the story of six generations over two centuries, starting with Kunta Kinte, a man from the Gambia who fell into slavery. At first, the work was classified as documentary prose as the writer argued that the main story was true and based on documentary, archival and library sources. However, after litigation regarding borrowing and claims about factual errors, the book was redefined as an autobiographical novel. Like the novels by T. Asemkulov and L. Ulitskaya, it is based on the idea of preserving "roots", that is the national and cultural identity, the national image of the world in the context of oppression. Interestingly, there is a theme song in the work and the soul of the people is embodied in music. The first thing Kunta hears as a baby hears is the rhythmic tapping of wooden beaters. Every significant event in the African village is accompanied by the sounds of tom-toms. In slavery, the song becomes a cultural code passed on from parents to children. In the narrative aspect, the author uses both the third person (the story about the ancestors) and first person (the story about his search for his roots) narrative modes. This narrative is a synthesis of the author's own research and a description of how the world is perceived through the portrayal of the protagonists' characters. The system of characters makes it possible to argue that the distinctiveness of the characters is completely different from the author's persona. The writer wanted to portray a different picture of the world, which is embodied through a different narrative system.

Table 1 presents a comparative analysis of the three works examined in this study in the genre, poetic and narrative aspects. 
Table 1. Analysis of the works of this genre, poetic and narrative aspects

\begin{tabular}{|c|c|c|c|}
\hline & $\begin{array}{l}\text { A Life at Noon } \\
\text { by T. Asemkulov }\end{array}$ & $\begin{array}{l}\text { Jacob's Ladder } \\
\text { by L. Ulitskaya }\end{array}$ & $\begin{array}{l}\text { Roots } \\
\text { by A. Haley }\end{array}$ \\
\hline Genre & autobiographical novel & $\begin{array}{l}\text { autobiographical } \\
\text { novel }\end{array}$ & autobiographical novel \\
\hline Content & family story & family story & family story \\
\hline Idea & $\begin{array}{l}\text { the importance of } \\
\text { preserving national } \\
\text { identity in the conditions } \\
\text { of colonial and } \\
\text { totalitarian oppression }\end{array}$ & $\begin{array}{l}\text { the importance } \\
\text { of preserving } \\
\text { cultural identity } \\
\text { in the conditions } \\
\text { of colonial and } \\
\text { totalitarian } \\
\text { oppression }\end{array}$ & $\begin{array}{l}\text { the importance of } \\
\text { preserving national / } \\
\text { racial identity in the } \\
\text { conditions of colonial and } \\
\text { totalitarian oppression }\end{array}$ \\
\hline Name & symbolic & symbolic & symbolic \\
\hline Music & basic & a theme song & a theme song \\
\hline $\begin{array}{l}\text { Focus } \\
\text { on fiction }\end{array}$ & + & + & + \\
\hline $\begin{array}{l}\text { Mythologization } \\
\text { and idealization } \\
\text { of the past }\end{array}$ & $\begin{array}{l}\text { image of the ancestor } \\
\text { as an ideal }\end{array}$ & $\begin{array}{l}\text { image of the } \\
\text { ancestor } \\
\text { as an ideal }\end{array}$ & $\begin{array}{l}\text { image of the ancestor } \\
\text { as an ideal }\end{array}$ \\
\hline Narrative mode & 3rd person & 3rd person & 3rd and 1st person \\
\hline $\begin{array}{l}\text { The image of the } \\
\text { character }\end{array}$ & $\begin{array}{l}\text { separated from the real } \\
\text { author (another name, } \\
\text { etc.) }\end{array}$ & $\begin{array}{l}\text { separated from } \\
\text { the real author } \\
\text { (another name, } \\
\text { etc.) } \\
\end{array}$ & the distance is minimized \\
\hline $\begin{array}{l}\text { Diffusion of the } \\
\text { voices of the } \\
\text { author and the } \\
\text { characters }\end{array}$ & + & + & + \\
\hline
\end{tabular}

The analysis shows that different national literatures (Kazakh, Russian and American) have the same artistic reaction: the need to reflect the oppression of national and cultural identity is reflected through an autobiographical novel, which is characterized by the combination of facts and fiction allowing the writer to conceptualize painful problems of the post-colonial and post-totalitarian society.

On the basis of the three novels analysed, it was concluded that the protagonists have a dual identity - belonging to the author (his or her experiences are described through linguistic means and literary devices) and a character identity, which is shown by the detachment of the writer from the character he or she has created (Hochman, 1985). 
The fictional character ("homo fictus") is often identified with a physical person (the author), but the characters are only a fiction created through linguistic means. They also act as literary tools that create a kind of image of reality that resembles our own (Vainikka, 2006).

The study of the relationship between the real (biographical) author and the image of the author is based on the idea proposed by Kopytov, who interprets the author's image as "a kind of mental construct of three types: a) construct established in the mind of the recipient; b) construct described as a result of the research analysis based on multidisciplinary methods (aesthetics, the theory of literature, philosophy, history of literature, including the biographical method of literary criticism); c) as an atom of a certain cultural-historical molecule (schools)" (Kopytov, 2010, 13).

We share the position of Hogan (2013), who insists on the need to revise the fundamental problems of authorship and narration in light of the latter in cognitive science. Based on recent studies devoted to cognitive complexity, Hogan comes up with a new, original version of the author's presence in the work that is based on the effect of the emotional trust of the recipients. Arguing about the structure and key principles of narrative discourse, Hogan (2013) considers the effects of complex types of narration, including parallel plot, embedded narrative, and collective narrative ("we"). We believe that a cognitive approach to the problems of the author's representation in the text is productive.

Traditionally, the subject of analysis in literary criticism was the veracity of autobiographical works, the search for coincidences and discrepancies in the real biography and literary text. However, modern researchers offer a completely new approach, which seems to be more productive. Thus, Boldyreva considers the postulate of fictitiousness of any autobiographical novel as a special model rather than a reflection of reality, since the main causal dominant of any autobiographical act is the focus on the author's life story containing beneficial facts rather than an objective story (Boldyreva, 2017, 245). Reece (2014) proposes qualifying such literature as a new hybrid literary genre of creative nonfiction. Moreover, Chemodurova (2019) notes that in modern literature autobiographical mimetism is being replaced by diverse autobiographical narratives, which are "a bizarre combination of factual and fictional components that allows modern authors to explore the global problems of representing personality, time, space, and memory mechanisms in order to offer readers unexpected and original narrative moves and solutions".

Given the above, it is difficult to agree with Rozanova (2003) who argues that "the author's inability to distance from a character is almost disastrous nowadays. The literary text immediately loses artistic convention and becomes similar to diary revelations. On the contrary, the boundaries between the position of the author and the position of the character become conditional" (Rozanova, 2003, 151). As a rule, "diary revelations" can be classified as stylization (for example, this is observed in "Jacob's Ladder" by L. Ulitskaya) that aims to better convey the ideas and position of the author. 
We completely agree with Nekrasova (2016), who insists on the need for typologization of autobiographical prose, the study of various types of author's representation and the prospects of this direction in literary criticism. The researcher refers to "life stories", memories, impressions, events, and a "human document". Autobiographical writing has been dominant in certain periods, such as in the era of Romanticism. A deeper understanding of the specifics of the return to this trend will be observed in the near future. Narrative and plot strategies bring sincerity and artistry to literature (Nekrasova, 2016, 133), and in the authors' opinion it is sincerity and artistry that are associated with the popularity of the literary works considered in this study (all of them have large readerships, they have been translated into numerous languages, and the novel Roots has been successfully filmed) (Tsvetkova, 2017).

We are sure that different versions of theoretical modelling and the practical study of new modifications of the author's presence in autobiographical literature are not the basis for separation, but rather determine the prospects for synthesis.

\section{Conclusions}

Based on the analysis of the Kazakh, Russian and American literature presented above, it has been concluded that the development of post-colonial and post-totalitarian discourse is reflected in updating the genre of an autobiographical novel that gives the author some freedom to choose factual material and fictional elements, and, as a result, the additional possibilities of artistic generalization. The main idea of such works is maintaining national/racial and cultural identity, and the national image of the world in the conditions of colonial and totalitarian oppression. An autobiographical novel is characterized, on the one hand, by relying on the real facts of the author's biography, and on the other, by mythologization and idealization of the past (the image of the ancestor as an ideal), and a focus on fiction. The dominant narrative practices are the third person narrative mode, the distance between the real author and the character, diffusion of the voices of the author and the characters. An autobiographical novel can be classified as a hybrid genre that is focused on a specific real life story in order to express a complex of ideas. In turn, a certain distance between the author and the character is determined by the desire of the real author to increase the typicality and universality of his or her own life story within the framework of understanding the author's image of the world as part of the national image of the world. The narrator is close to the real author, but not identical. This key feature of an autobiographical novel prevents possible distortions in the reception and interpretation of such works.

The practical significance of the research lies in the fact that its results can be used to study the problems of the theory and history of literature, as well as to give special courses in higher educational institutions. 


\section{References}

Azizova, A.O., Dzholdasbekova B.U., Intellectual prose of Kazakhstan of the independence period, Bulletin of Russian University of People's Friendship, Literary Criticism. Journalism 1, 2016, pp. 84-89.

Bogdanova, E.S., The image of the author and author's subjectivity in the methodology of teaching perception of a literary text, Scientific Notes of ZabSU 11 (6), 2016, pp. 107-114.

Boldyreva, E.M., Autobiographism and autobiography: self-construction and semiotization of the subject, Yaroslavl Pedagogical Bulletin 4, 2017, pp. 242-251.

Chemodurova, Z.M., Strategies for creating a modern autobiographical text in English, Bulletin of Herzen State Pedagogical University 192, 2019, pp. 52-59.

Hogan, P.C., Narrative Discourse: Authors and Narrators in Literature, Film, and Art, Columbus, 2013.

Jiao, W., Autobiography as a literary genre formation: nature, varieties and modern modifications, Scientific Notes of Petrozavodsk State University 3 (180), 2019, pp. 49-53.

Kopytov, O.N., The image of the author and the author's element: differentiation and areas of application of concepts, Bulletin of Tomsk State University 334, 2010, pp. 11-14.

Moroz, N.A., Means of expression of subjective modality of a literary text, Bulletin of SUSU 'Linguistics' 14 (3), 2017, pp. 29-33.

Nekrasova, I.V., Expanding the boundaries of documentary works of the latest Russian literature, Philology and Culture 3 (45), 2016, pp. 129-134.

Orlova, E.I., The Forms of the Author's Presence in a Literary Work, Moscow 2017.

Rakhmatova, A.M., Incomplete image of a human in the culture of the 19th - 20th centuries (from Dostoevsky to non-classical lyrics), Bulletin of Kemerovo State University of Culture 41, 2017, pp. 111-117.

Richardson, B., Unnatural Voices. Extreme Narration in Modern and Contemporary Fiction, Columbus 2006.

Rozanova, M., The first person of the main character, Continent 116, 2003, pp. 149-160.

Sokolov, A.V., Bibliopsychology and noosphere, Bibliotekovedenie [Russian Journal of Library Science] 66 (4), 2017, pp. 378-385.

Tsvetkova, M., Media culture book-centered films - a social doping for the reading, Media Education, 4, 2017, pp. 126-147. Hochman, B., Character in Literature, Ithaca 1985.

Vainikka, E., Homo Fictus: kuvitteellinen henkilö virtuaalitodellisuudessa, Tampere, 2006.

Yankovskaya, L.S., Autobiography or autopsychology? The Presence of the author in the artistic narration, Bulletin of Saratov State University. Series: Philology. Journalism 18 (1), 2018, pp. 87-91. 


\section{The importance of separating the author from the narrative in modern and classical literature}

Keywords: autobiographical novel, image of the world, narrative practices, author's identity, post-colonial and post-totalitarian discourses

The purpose of the study is to analyse the autobiographical works by contemporary Kazakh, Russian and American writers of the late twentieth and early twenty-first centuries belonging to the post-colonial and post-totalitarian discourses in terms of the specificity of the author's representation. Based on a literature analysis, it has been concluded that the development of post-colonial and post-totalitarian discourse is reflected in updating the genre of an autobiographical novel that gives the author some freedom to choose factual material and fictional elements as part of the artistic embodiment of the author's vision of the world. The main ideas of such works are maintaining national/racial and cultural identity and preserving historical and cultural continuity within the framework of the national image of the world. An autobiographical novel is characterized, on the one hand, by relying on the real facts of the author's biography, and on the other, by mythologization and idealization of the past, and a focus on fiction. This key feature of an autobiographical novel prevents possible distortions in the reception and interpretation of such works, mixing the author's image of the world and a specific historical and cultural situation, which is expressed by the autobiographical novel.

\section{Pomembnost razlikovanja med avtorjem in pripovedovalcem $\mathbf{v}$ moderni in klasični literaturi}

Ključne besede: avtobiografski roman, podoba sveta, pripovedni postopki, avtorjeva istovetnost, postkolonialni in posttotalitarni diskurzi

Namen študije je analizirati avtobiografska dela sodobnih kazahstanskih, ruskih in ameriških pisateljev poznega 20. in začetka 21. stoletja, ki spadajo v postkolonialni in posttotalitarni diskurz glede na specifičnost njihove predstavitve. Na podlagi analize je bilo ugotovljeno, da se razvoj postkolonialnega in posttotalitarnega diskurza odraža v posodabljanju žanra avtobiografskega romana, ki avtorju dopušča nekaj svobode pri izbiri stvarnega gradiva in fikcijskih elementov kot dela umetniškega utelešenja avtorjeve vizije sveta. Glavne ideje takšnih del so ohranjanje nacionalne/rasne in kulturne identitete ter ohranjanje zgodovinske in kulturne kontinuitete $\mathrm{v}$ okviru nacionalne podobe sveta $\mathrm{v}$ razmerah kolonialnega in totalitarnega zatiranja. Za avtobiografski 
roman je po eni strani značilno zanašanje na resnična dejstva avtorjeve biografije, po drugi strani pa mitologizacija in idealizacija preteklosti ter osredotočenost na fikcijo. Ta ključna značilnost avtobiografskega romana preprečuje morebitna izkrivljanja v recepciji in interpretaciji tovrstnih del, meša avtorjevo podobo sveta in specifično zgodovinsko in kulturno situacijo, ki jo izraža avtobiografski roman.

\section{About the authors}

Milena Tsvetkova is a Doctor, Associate Professor at the Faculty of Journalism and Mass Communication of Sofia University, Moskovska str., 49, Sofia, 1000, Bulgaria. Email: milena_tsvetkova13@rambler.ru.

Yuri Kolin is a PhD, Head of Science Programs at the Department of Theory of Culture of the Institute of Civil Society, Aliza Yansen str., 67912, Or-Akiva, 306000, Israel. He also works at the Institute of Philosophy and Socio-Political Sciences of the Southern Federal University, Russian Federation. Email: yu.ko776@rambler.ru.

Yuliya Bakhnova is an Associate Professor at the Department of Foreign Languages № 3 of G.V. Plekhanov Russian University of Economics, Stremyanny lane, 36, Moscow, 117997, Russian Federation. Email: bahnova2011@mail.ru.

Svetlana Salimova is a Candidate of pedagogical science at the Department of English Language for Professional Purposes of N. P. Ogarev Mordovia State University, Botevgradskaya str., 29/1, Saransk, 430005, Russian Federation. Email: svsalim987@ rambler.ru.

\section{O avtoriih}

Milena Tsvetkova je izredna profesorica na Fakulteti za novinarstvo in množično komuniciranje Univerze v Sofiji, Moskovska str., 49, Sofija, 1000, Bolgarija. Elektronski naslov: milena_tsvetkova13@rambler.ru.

Yuri Kolin je doktor znanosti, vodja znanstvenih programov na Oddelku za teorijo kulture Inštituta za civilno družbo, Aliza Yansen str., 67912, Or-Akiva, 306000, Izrael. Dela tudi na Inštitutu za filozofijo in družbeno-politične vede Južne zvezne univerze v Ruski federaciji. Elektronski naslov: yu.ko776@rambler.ru. 
Yuliya Bakhnova je izredna profesorica na Oddelku za tuje jezike št. 3 Ruske ekonomske univerze Plekhanov v Moskvi, Ruska federacija. Elektronski naslov: milena_tsvetkova13@rambler.ru (kontaktna oseba).

Svetlana Salimova je doktorandka pedagogike na Oddelku za angleški jezik za strokovne namene Mordovijske državne univerze N. P. Ogareva, Botevgradskaya str., 29/1, Saransk, 430005, Ruska federacija. Elektronski naslov: svsalim987@rambler.ru. 